\title{
Effects of subchronic exposure to atrazine on zebrafish (Danio rerio)
}

\author{
L. Plhalova ${ }^{1}$, J. Blahova ${ }^{1}$, I. Mikulikova ${ }^{1}$, S. Stepanova ${ }^{1}$, P. Dolezelova ${ }^{1}$, \\ E. Praskova ${ }^{1}$, P. Marsalek ${ }^{1}$, M. Skoric ${ }^{2}$, V. Pistekova ${ }^{1}$, I. Bedanova ${ }^{1}$, \\ Z. Svobodova ${ }^{1}$
}

${ }^{1}$ Department of Veterinary Public Health and Toxicology, Faculty of Veterinary Hygiene and Ecology,
University of Veterinary and Pharmaceutical Sciences Brno, Palackeho 1/3, 612 42 Brno, Czech Republic
${ }^{2}$ Department of Pathological Morphology, Faculty of Veterinary Medicine,
University of Veterinary and Pharmaceutical Sciences Brno, Palackeho 1/3, 61242 Brno, Czech Republic

\begin{abstract}
The aim of this study was to investigate the effects of subchronic exposure to atrazine on fish growth and the development of histopathological changes in selected organs (gill, kidney, liver) in Danio rerio. Juvenile growth tests were performed on D. rerio according to OECD method No. 215. For 28 days, fish at an initial age of 30 days were exposed to the environmental atrazine concentration commonly detected in Czech rivers $(0.3 \mu \mathrm{g} / \mathrm{L})$ and a range of sublethal concentrations of atrazine (3.0, 30.0 and $90.0 \mu \mathrm{g} / \mathrm{L}$ ). The results showed decreasing growth rates and morphological changes in the liver (dystrophic lesions of hepatocytes) at $90.0 \mu \mathrm{g} / \mathrm{L}$ of atrazine. The environmental concentration of atrazine in Czech rivers did not have any effect on fish growth and development of histopathological changes in D. rerio. The value of NOEC was $30.0 \mu \mathrm{g} / \mathrm{L}$ and the value of LOEC was $90.0 \mu \mathrm{g} / \mathrm{L}$.
\end{abstract}

Key words: Zebrafish, growth test, histopathology, triazine herbicide

Abbreviations and Units: DMSO - dimethyl sulfoxide; GC/IT-MS - gas chromatography with ion trap mass spectrometry; NOEC - no observed effect concentration; LC50 - 50\% lethal concentration; LOEC - lowest observed effect concentration; OECD - Organization for Economic Cooperation and Development.

\section{Introduction}

Atrazine (2-chloro-4-ethylamino-6-isopropylamino-1,3,5-triazine) is one of the most widely used triazine herbicides in the world. Atrazine (molecular weight 251.7) is used for pre- and post-emergence control of annual grass and broad-leaved weeds in maize, sorghum, asparagus, vines, top-fruit, citrus, sugar cane, bananas, coffee, oil palms and grass- land/forestry, the major uses being maize and sorghum. It is used in combination with many other herbicides (Steinberg et al. 1995, Roberts et al. 1998, Alvarez and Fuiman 2005, Zhou et al. 2008). Atrazine is a selective systemic herbicide which acts as a photosynthesis inhibitor. It is absorbed by roots and leaves, is translocated acropetally in the xylem and accumulates in the apical meristems (Roberts et al. 1998). 
Due to the heavy use of atrazine and its persistence in surface and ground waters, it is considered to be a potential risk for water quality. Metabolites of atrazines are, however, more persistent and high concentrations have been reported long after the application season. Thus, its use is increasingly restricted in many countries (Steinberg et al. 1995, Graymore et al. 2001, Zhou et al. 2008). The extent of contamination by triazine herbicides in the aquatic environment depends not only on contaminant inputs but also on the persistence of these compounds within this environment as determined by $\mathrm{pH}$, salinity, oxygen availability, temperature, organic matter and moisture content (Fletcher et al. 1994). Preparations containing atrazine have not been registered in the Czech Republic since 2006, but atrazine and its degradation products are still detected in the aquatic environment in the Czech Republic. The highest concentration of atrazine in surface water reported in 2008 was $0.3 \mu \mathrm{g} / \mathrm{L}$ (data from the Czech Hydrometeorogical Institute). The aim of this study was to investigate the effects of subchronic exposure to atrazine on fish growth and the development of histopathological changes in selected organs (gill, kidney, liver) in Danio rerio.

\section{Materials and Methods}

\section{Experimental fish}

Tests of atrazine toxicity were performed on Danio rerio, which is one of the model organisms most commonly used in toxicity tests (Lele and Krone 1996, Yang et al. 2009). Experimental procedures were in compliance with national legislation (Act No. 246/1992 Coll., on the Protection of Animals Against Cruelty, as amended, and Decree No. 207/2004 Coll., on the Protection, Breeding and Use of Experimental Animals, as amended).

\section{The subchronic toxicity test}

The tests were performed on $D$. rerio at the age of 30 days, according to OECD No. 215 Fish, Juvenile Growth Test with atrazine of $98.8 \%$ chemical purity (Sigma Aldrich). The fish were exposed to a range of sublethal concentrations of atrazine $(0.3 \mu \mathrm{g} / \mathrm{L}-$ environmental concentration in Czech rivers, 3.0, 30.0 and $90.0 \mu \mathrm{g} / \mathrm{L}$ ) for 28 days. The test compound was dissolved in water using dimethyl sulfoxide (DMSO), which is the most commonly used delivery system for water-insoluble chemicals in aquatic bioassays (Hallare et al. 2006, Machova et al. 2009). The concentration of DMSO reached $0.01 \%$ in all atrazine test con- centrations and DMSO control, and this level of concentration is allowed according to OECD methodology. We did not find any significant differences in any test parameters between the control group with dilution water only in comparison with the control group with DMSO.

The fish were randomly distributed into $30 \mathrm{~L}$ glass aquariums, 40 specimens for each. The test on an atrazine treated group was performed in duplicate (80 fish for each concentration). The experiment was conducted in a flow-through system (Fig. 1) and the volume of test solutions was replaced twice a day. The average initial weight of fish used in the experiment

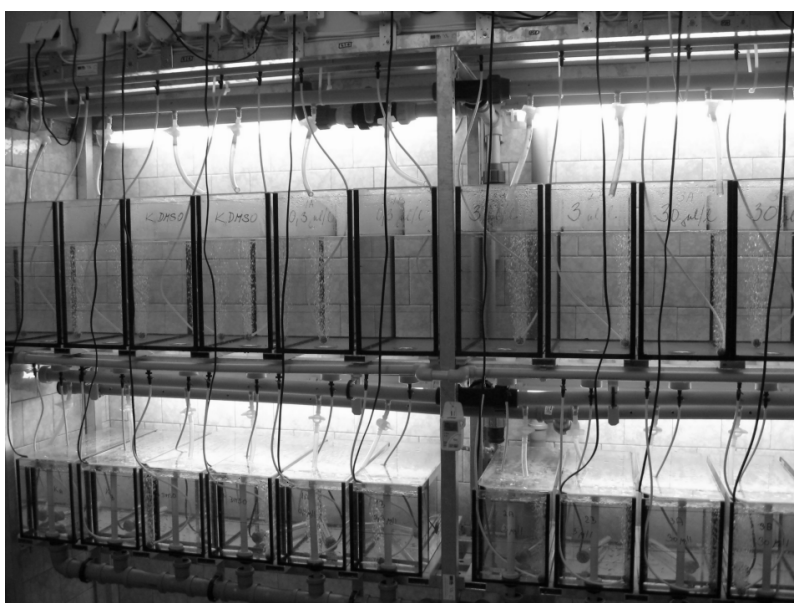

Fig. 1. View of the flow-through system.

was $0.031 \pm 0.015 \mathrm{~g}$. The fish were fed with dried $\mathrm{Ar}$ temia salina without nutshells to the amount of $8 \%$ of their body weight per day; the food ration was based on initial fish weights and was recalculated after 14 days. At the end of the tests, the fish were euthanized by carbon dioxide, weighed and their tank-average specific growth rates were determined. Food was withheld from the fish $24 \mathrm{~h}$ prior to weighing. During the tests, living conditions were checked at 24-hour intervals and the number of dead fish was recorded in each concentration. The mean values for water quality were: temperature $25 \pm 1^{\circ} \mathrm{C}$, oxygen saturation above $60 \%$ (ranging from $78 \%$ to $96 \%$ ), $\mathrm{pH}$ from 7.95 to 8.28. The basic chemical parameters of dilution water used were: $\mathrm{COD}_{\mathrm{Mn}}$ (chemical oxygen demand) 1.5 $-1.7 \mathrm{mg} / \mathrm{L}$; total ammonia below the limit of determination $(<0.04 \mathrm{mg} / \mathrm{L}) ; \mathrm{NO}_{3}^{-} 25.1-29.7 \mathrm{mg} \mathrm{l}^{-1} ; \mathrm{NO}_{2}^{-}$ below the limit of determination $(<0.02 \mathrm{mg} / \mathrm{L}) ; \mathrm{Cl}^{-}$ 18.2 - $18.9 \mathrm{mg} / \mathrm{L} ; \Sigma \mathrm{Ca} \pm \mathrm{Mg} 14 \mathrm{mg} / \mathrm{L}$.

Tank-average specific growth rates were calculated using the following formula according to OECD No. 215: 


$$
r=\frac{\overline{\log _{e} W_{2}}-\overline{\log _{e} W_{1}}}{t_{2}-t_{1}} \cdot 100
$$

$r$ - tank-average specific growth rate

$W_{1}, W_{2}$ - weights of a particular fish at times $t_{1}$ and $t_{2}$ respectively

$\overline{\log _{e} W_{1}}$ - average of the logarithms of the values $W 1$ for the fish in the tank at the start of the study period

$\overline{\log _{e} W_{2}}$ - average of the logarithms of the values $W 2$ for the fish in the tank at the end of the study period

$t_{1}, t_{2}$ - time (days) at the start and end of the study period

\section{Statistical analysis}

Data were subjected to Kruskal-Wallis one-way ANOVA and subsequently to Dunnett's test in order to assess the statistical significance of differences in tank-average fish specific growth rates between test groups with different concentrations and those of the control groups. The estimation of the LOEC and NOEC was based on ANOVA followed by Dunnett's test for the identification of the lowest concentration at which these differences of specific growth rate were (were not) significant at a 0.05 probability level, and, further, on the results of histopathological examination and the assessment of changes in fish behaviour.

\section{Determination of atrazine}

Gas chromatography with ion trap tandem mass spectrometry (GC/IT-MS) was used for the determination of atrazine. A sample preparation was based on simple liquid-liquid extraction into cyclohexane.

Separation, identification and quantification were based on the GC/IT-MS method. A Varian 450-GC gas chromatograph (Varian Inc., USA) and VF-5ms $(30 \mathrm{~m} \times 0.25 \mathrm{~mm})$ column were used for separation. A Varian 220-MS (Varian Inc., USA) ion trap mass spectrometer was used for identification and quantification. Chromatographic and MS conditions were based on the method described by Perreau and Einhorn (2006). All solvents were of GC/MS-grade purity (Chromservis, s.r.o., CZ). A certified standard of atrazine was purchased from Dr. Ehrenstorfer $\mathrm{GmbH}$ (Germany).

The detection limit $(3 \sigma)$ for atrazine was 0.04 $\mu \mathrm{g} / \mathrm{L}$. Expanded uncertainty was $6.3 \%$ on the condition that the coefficient of expansion was $\mathrm{k}=2$.

\section{Histopathological examination}

The fish (10 specimens from each concentration) were prepared for histopathological examination (on selected organs - gill, kidney, liver), fixed in buffered $10 \%$ neutral formalin, dehydrated, embedded in paraffin wax, sectioned on a microtome at a thickness of $4 \mu \mathrm{m}$, and stained with haematoxylin and eosin (HE). Five sections from each fish were examined at different levels.

\section{Results}

\section{Mortality and fish behaviour}

The fish were exposed to 4 sublethal concentrations of atrazine. The effects of the environmental concentration in Czech rivers $(0.3 \mu \mathrm{g} / \mathrm{L})$ and concentrations 10 -fold $(3.0 \mu \mathrm{g} / \mathrm{L}), 100$-fold $(30.0 \mu \mathrm{g} / \mathrm{L})$ and 300 -fold $(90.0 \mu \mathrm{g} / \mathrm{L})$ were assessed. In all test groups and in the control group, mortality did not exceed $5 \%$ during the 28-day experimental period.

In test groups exposed to sublethal concentrations of atrazine $(0.3 \mu \mathrm{g} / \mathrm{L}$ - environmental concentration in Czech rivers, 3.0, 30.0 $\mu \mathrm{g} / \mathrm{L}$ ) we did not notice any changes in fish behaviour. However, at the $90.0 \mu \mathrm{g} / \mathrm{L}$ concentration we noticed decreased food intake compared to the control group (the fish showed no interest in food and its residues accumulated at the bottom of the tank).

\section{Growth rate}

The initial body weights were not significantly different between groups, but at the end of the trial, body weights in tanks with a $90.0 \mu \mathrm{g} / \mathrm{L}$ concentration of atrazine were significantly lower $(p<0.05)$ compared to the control group (mean \pm SEM). The values of specific growth rate $r$ for the test groups in comparison with the control group are shown in Fig. 2.

\section{Histopathology}

Histopathological examination revealed pathological lesions in pesticide-exposed fish only in the experimental group with the highest concentration of atrazine $(90 \mu \mathrm{g} / \mathrm{L})$. Morphological changes were observed in the liver and were represented by moderate dystrophic lesions of hepatocytes. There were morphological signs of initial cell injury represented by the hydropic to vacuolar degeneration of hepatocytes, the dilatation of capillaries and hyperaemia 


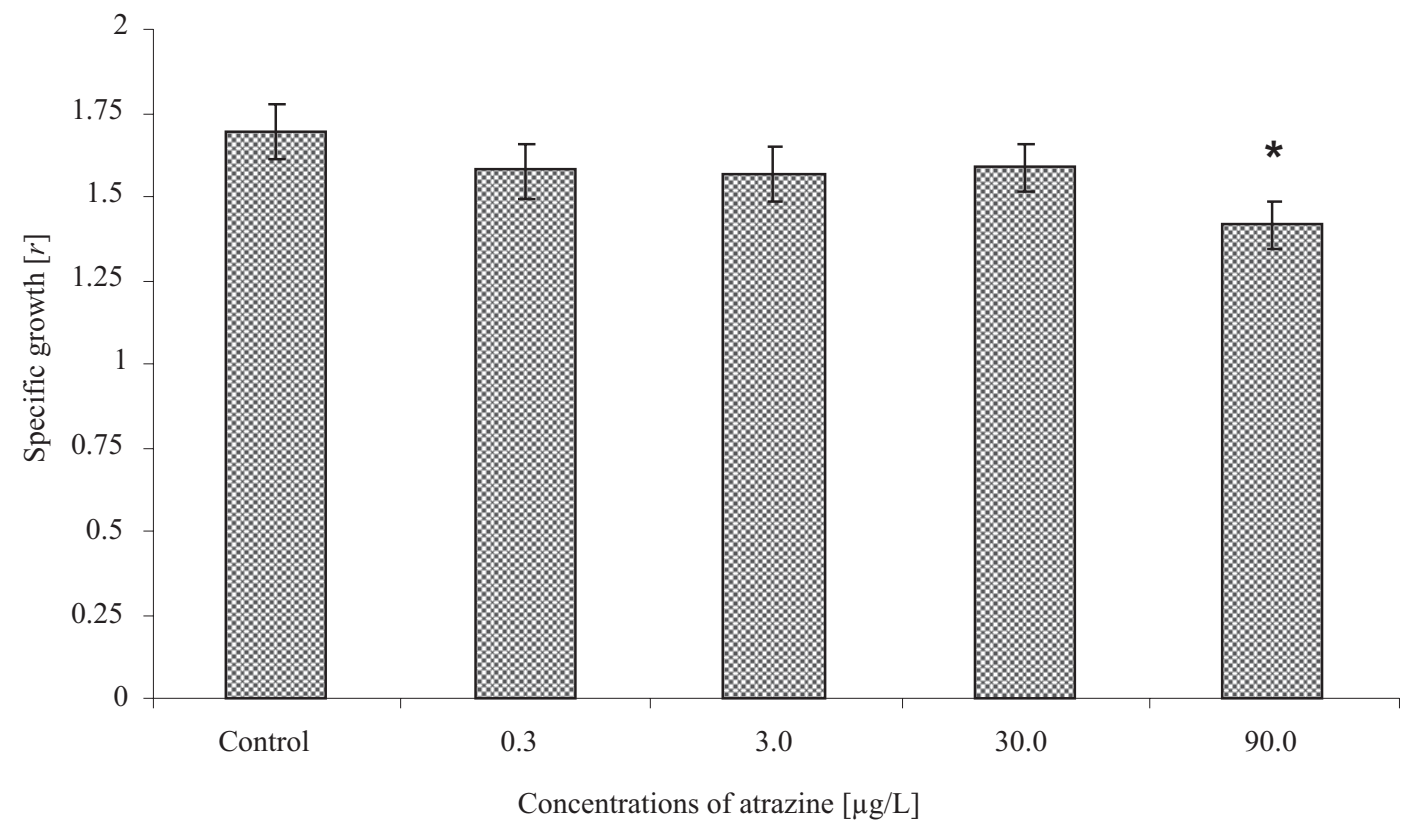

Fig. 2. Comparison of specific growth rate $(r)$ (mean \pm SEM) for control and tested atrazine concentrations (concentrations of atrazine from $0.3 \mu \mathrm{g} / \mathrm{L}$ to $90 \mu \mathrm{g} / \mathrm{L})\left({ }^{*} \mathrm{p}<0.05\right)$.
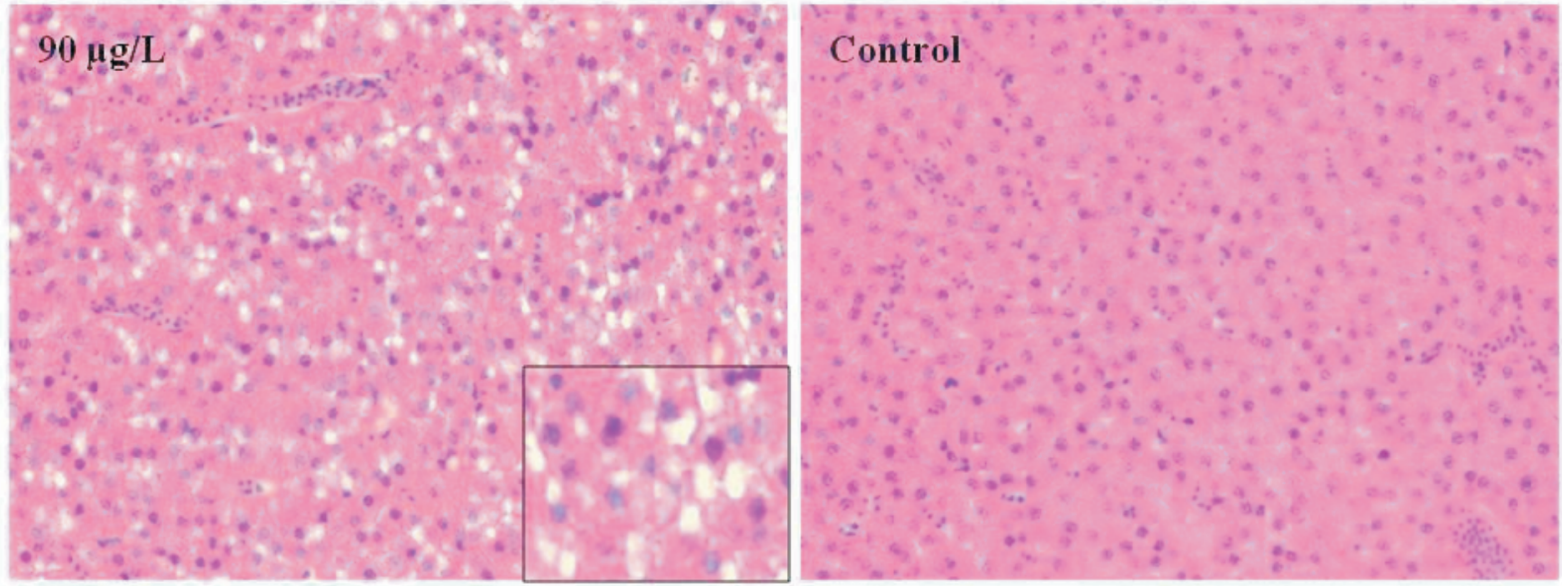

Fig. 3. View of the liver of zebrafish - Hydropic to vacuolar degeneration of hepatocytes, dilatation of capillaries and hyperaemia in the liver of Danio rerio exposed to atrazine at a concentration of $90.0 \mu \mathrm{g} / \mathrm{L}$ for 28 days $(\mathrm{HE}, 400 \mathrm{x})$.

(Fig. 3). All affected tissues were histopathologically compared with tissue sections from the negative control group (without DMSO) (Figure 3). All the animals in this group had the same intensity of morphological changes in the liver and the changes were throughout the organ. Tissues and organs from the fish in experimental groups exposed to atrazine at concentrations of $0.3 \mu \mathrm{g} / \mathrm{L}, 3.0 \mu \mathrm{g} / \mathrm{L}$ and $30.0 \mu \mathrm{g} / \mathrm{L}$ exhibited no pathomorphological changes.

\section{Validity of the tests}

Our tests met all conditions required by the OECD - mortality in both control groups was below
$10 \%$, the final weight of control fish was higher than $150 \%$ of the initial weight, the dissolved oxygen concentrations were at least $60 \%$, the water temperature did not differ by more than $\pm 1^{\circ} \mathrm{C}$ among test aquariums, and test substance concentrations were above $80 \%$ of the measured initial concentration.

\section{Discussion}

The effects of acute exposure to atrazine have been documented for many fish species. For silver catfish (Rhamdia quelen) the atrazine 96-h LC50 was $10.2 \mathrm{mg} / \mathrm{L}(9.0-11.5 \mathrm{mg} / \mathrm{L})$ (Kreutz et al. 2008), for common carp (Cyprinus carpio) $18.8 \mathrm{mg} / \mathrm{L}$ (Neskovic 
et al. 1993), and for bluegill sunfish (Lepomis macrochirus) $16.0 \mathrm{mg} / \mathrm{L}$ (Bathe et al. 1973). The Nile fish Oreochromis niloticus (96-h LC50 $9.37 \mathrm{mg} / \mathrm{L}$ ) and Chrysichthyes auratus $(6.37 \mathrm{mg} / \mathrm{L})$ have a similar sensitivity to atrazine (Hussein et al. 1996). The freshwater fish Channa punctatus is less sensitive according to Nwani et al. (2010), who determined the 96-h LC50 for this species to be $42.381 \mathrm{mg} / \mathrm{L}$.

However due to the potential of triazines to bioaccumulate in organisms and remain active there for a long time (Rioboo et al. 2007), it is relevant to study also the sublethal effects of these triazine herbicides on fish and other aquatic organisms (Modra et al. 2008, Velisek et al. 2011). Many studies such as Steinberg et al. (1995), Saglio and Trijasse (1998), Alvarez and Fuiman (2005), Tryfonos et al. (2009) and de Campos Ventura et al. (2008), have dealt with the determination of the effects of subchronic exposure of fish to atrazine - effects on fish behavior and on biometric, histopathological, hematological and biochemical parameters, as well as many other impacts on the fish organism. In our study we focused on the effects of subchronic exposure of environmental concentration and other sublethal concentrations of atrazine on zebrafish (Danio rerio).

We observed the influence of sublethal concentrations of atrazine on mortality and fish behaviour. Whereas the mortality in our tests in all tanks (the highest atrazine concentration was $90 \mu \mathrm{g} / \mathrm{L}$ ) did not exceed 5\% during the 28-day experimental period, Nieves-Puigdoller et al. (2007) recorded the higher mortality (9\%) at a concentration of $100 \mu \mathrm{g} / \mathrm{L}$ of atrazine in Atlantic salmon (Salmo salar) smolts after a 21 day exposure. In our test at the highest concentration of atrazine $(90 \mu \mathrm{g} / \mathrm{L})$ fish only swam in the middle of the tank with no signs of interest in food compared to control. According to Steinberg et al. (1995), decreased food intake, which we noticed in test and other alterations in swimming behaviour, could be caused by the effect of atrazine on the sensory organs and nervous system.

Our results showed decreasing growth rates only at the $90 \mu \mathrm{g} / \mathrm{L}$ concentration of atrazine, but Alvarez and Fuiman (2005) found reduced growth rates and prolongation of the larval period in red drum larvae (Sciaenops ocellatus) at a lower concentration (40 $\mu \mathrm{g} / \mathrm{L}$ and $80 \mu \mathrm{g} / \mathrm{L}$ of atrazine) after only 4 days of exposure. Likewise Nieves-Puigdoller et al. (2007) detected in Altlantic salmon smolts during a 3 month stay in seawater a reduction in food intake and growth as a results of atrazine exposure (in fresh water), which caused osmoregulatory disturbance and physiological stress. Similarly, Waring and Moore (2004) found that exposure to atrazine in fresh water (to 10 $\mu \mathrm{g} / \mathrm{L}$ and $22.7 \mu \mathrm{g} / \mathrm{L}$ ) for 7 days reduced salinity toler- ance in Atlantic salmon smolts. They considered atrazine affects on gill ion flux activity as the cause of mortality after the transfer of fish to sea water.

The effect of various aquatic environmental pollutants on the gill epithelium, which is the site of gas change, acid-base balance, ionic regulation and nitrogenous waste excretion, can be connected to morphological pathologies, alternations in blood levels, and ionic fluxes (Evans 1987). However, we did not find any histopathological changes in the gills in any treated group. Alazemi et al. (1996) decribed damage to the gill epithelium, but at a higher concentration $(0.5 \mathrm{mg} / \mathrm{L}$ of atrazine) after 6 hours of exposure.

Many authors observed pathomorphological changes in the kidney, caused by atrazine exposure. Fisher-Scherl et al. (1991) and Oulmi et al. (1995) detected cytopathological alterations in the renal tubules of rainbow trout (Oncorhynchus mykiss) after 28 days of exposure at concentrations lower than in our experiment. Fisher-Scherl et al. (1991) described alterations to the different components of renal corpuscles and of renal tubules in rainbow trout, as well as an increase in cells with mitotic figures in the renal hemopoietic interstitium. In addition, Oulmi et al. (1995) detected cytopathological alterations in renal tubules already at an atrazine concentration of 10 $\mu \mathrm{g} / \mathrm{L}$. The necrosis of endothelial cells and renal hemopoietic tissue was found in Oncorhynchus mykiss at atrazine concentrations of $80 \mu \mathrm{g} / \mathrm{L}$ (after 28 days) and also after short-term exposure (96 hours) at concentrations of $1.4 \mathrm{mg} / \mathrm{L}$ and $2.8 \mathrm{mg} / \mathrm{L}$. These results were supported by Hussein et al. (1996), who determined significantly increased levels of urea nitrogen in serum in Chrysichthyes auratus after exposure to atrazine concentrations of $3.0 \mathrm{mg} / \mathrm{L}$ and $6.0 \mathrm{mg} / \mathrm{L}$ for 28 days, which may be due to the result of such damage. These results demonstrate the high nephrotoxic potential of atrazine in fish (Oulmi et al. 1995). In contrast to these findings, the results of our study did not show any pathomorphological changes in the kidney of Danio rerio at any atrazine concentration.

The only changes that we found in our test were morphological changes in the liver (the hydropic to vacuolar degeneration of hepatocytes, the dilatation of capillaries and hyperaemia) at the highest atrazine concentration $(90 \mu \mathrm{g} / \mathrm{L})$. Likewise, Braunbeck et al. (1992) and Jin et al. (2012) demonstrated damage to hepatic cells, but at much lower concentrations than our results showed. According to Jin et al. (2012), atrazine also altered a number of hepatic proteins, which are involved in a variety of biological processes including oxidative stress, which atrazine may cause (Elia et al. 2002, Nwani et al. 2010).

In the light of the above findings, atrazine NOEC (no observed effect concentration) and LOEC (lowest 
observed effect concentration) were determined in the present study. For an exposure period of 28 days the values of NOEC and LOEC were $30.0 \mu \mathrm{g} / \mathrm{L}$ and $90.0 \mu \mathrm{g} / \mathrm{L}$, respectively.

\section{Conclusions}

On the basis of our results, it was concluded that the environmental concentration of atrazine detected in Czech rivers $(0.3 \mu \mathrm{g} / \mathrm{L})$ has no effect on fish behaviour or mortality, on growth, or on the development of histopathological changes in D. rerio, and that this concentration is lower than the determined values of LOEC and NOEC for atrazine.

\section{Acknowledgements}

This research was supported by GACR P502/12/P163.

\section{References}

Alazemi BM, Lewis JW, Andrews EB (1996) Gill damage in the freshwater fish Gnathonemus petersii (family: Mormyridae) exposed to selected pollutants: an ultrastructural study. Environ Technol 17: 225-238.

Alvarez MC, Fuiman LA (2005) Environmental levels of atrazine and its degradation products impair survival skills and growth of red drum larvae. Aquat Toxicol 74: 229-241.

Bathe R, Ullmann L, Sachsse K (1973) Determination of pesticide toxicity to fish. In: Schriftenr Ver Wasser-Boden-Lufthyg (ed), Berlin-Dahlem 37: 241-256 (in German).

Braunbeck T, Burkhardt-Holm P, Gorge G, Nagel R, Negele RD, Storch V (1992) Rainbow trout and zebrafish, two models for continuous toxicity tests: relative sensitivity, species and organ specifity in cytopathologic reaction of liver and intestines to atrazine. Schriftenr Ver Wasser Boden Lufthyg 89: 109-145.

de Campos Ventura B, de Angelis DF, Marin-Morales MA (2008) Mutagenic and genotoxic effects of the atrazine herbicide in Oreochromis niloticus (Perciformes, Cichlidae) detected by the micronuclei test and the comet assay. Pestic Biochem Physiol 90: 42-51.

Elia AC, Waller WT, Norton SJ (2002) Biochemical responses of bluegill sunfish (Lepomis macrochirus, Rafinesque) to atrazine induced oxidative stress. Bull Environ Contam Toxicol 68: 809-816.

Evans DH (1987) The fish gill: site of action and model for toxic effects of environmental pollutants. Environ Health Perspect 71: 47-58.

Fisher-Scherl T, Veeser A, Hoffmann RW, Kuhnhauser C, Nelege RD, Ewringmann T (1991) Morphological effects of acute and chronic atrazine exposure in rainbow trout (Oncorhynchus mykiss). Arch Environ Contam Toxicol 20: 454-461.
Fletcher CA, Meakins NC, Bubb JM, Lester JN (1994) Magnitude and distribution of contaminants in salts-marsh sediments of the Essex coast, UK. III. Chlorophenoxy acid and $s$-triazine herbicides. Sci Total Environ 155: 61-72.

Graymore M, Stagnitti F, Allinson G (2001) Impacts of atrazine in aquatic ecosystems. Environ Int 26: 483-495.

Hallare A, Nagel K, Kohler HR, Triebskorn R (2006) Comparative embryotoxicity and proteotoxicity of three carrier solvents to zebrafish (Danio rerio) embryos. Ecotox Environ Saf 63: 378-388.

Hussein SY, El-Nasser MA, Ahmed SM (1996) Comparative studies on the effects of herbicide atrazine on freshwater fish Oreochromis niloticus and Chrysichthyes auratus at Assiut, Egypt. Bull Environ Contam Toxicol 57: 503-510.

Jin Y, Zhang X, Lu D, Fu Z (2012) Proteomic analysis of hepatic tissue in adult female zebrafish (Danio rerio) exposed to atrazine. Arch Environ Contam Toxicol 62: 127-134.

Kreutz Lc, Barcellos LJ, Silva TO, Anziliero D, Martins D, Lorenson M, Marteninghe A, da Silva LB (2008) Acute toxicity test of agricultural pesticides on silver catfish (Rhamdia quelen) fingerlings. Cięncia Rural 38: 1050-1055 .

Lele Z, Krone PH (1996) The zebrafish as a model system in developmental toxicological and transgenic research. Biotechnol Adv 14: 57-72.

Machova J, Prokes M, Kroupova H, Svobodova Z, Macova S, Dolezelova P, Velisek J (2009) Early ontogeny, growth and mortality of common carp (Cyprinus carpio) at low concentrations of dimethyl sulfoxide. Acta Vet Brno 78: 502-512.

Modra H, Haluzova I, Blahova J, Havelkova M, Kruzikova K, Mikula P, Svobodova Z (2008) Effects of subchronic metribuzin exposure on common carp (Cyprinus carpio). Neuroendocrinol Lett 29: 669-674.

Neskovic NK, Elezovic I, Karan V, Poleksic V, Budimir M (1993) Acute and subacute toxicity of atrazine to carp (Cyprinus carpio L.) Ecotoxicol Environ Saf 25: 173-182.

Nieves-Puigdoller K, Bjornsson BT, McCormick SD (2007) Effects of hexazinone and atrazine on the physiology and endocrinilogy of smolt development in Atlantic salmon. Aquat Toxicol 84: 27-37.

Nwani CD, Lakra WS, Nagpure NS, Kumar R, Kushwaha B, Srivastava SK (2010) Toxicity of the herbicide atrazine: effects on lipid peroxidation and activities of antioxidant enzymes in the freshwater fish Channa punctatus (Bloch). Int J Environ Res Public Health 7: 3298-3312.

Oulmi Y, Negele RD, Braunbeck T (1995) Segment specifity of the cytological responses in rainbow trout (Oncorhynchus mykiss) renal tubules following prolonged exposure to sublethal concentrations of atrazine. Ecotoxicol Environ Saf 32: 39-50.

Perreau F, Einhorn J (2006) Determination of frequently detected herbicides in water by solid-phase microextraction and gas chromatography coupled to ion-trap tandem mass spectrometry. Anal Bioanal Chem 386: 1449-1456.

Rioboo C, Prado R, Herrero C, Cid A (2007) Population growth study of the rotifer Brachionus sp. fed with triazine-exposed microalgae. Aquat Toxicol 83: 247-253.

Roberts TR, Hutson DH, Lee PW, Nicholls PH, Plimmer JR (1998) Metabolic Pathways of Agrochemicals, Part 1: Herbicides and plant growth regulators. 1st ed, Cambridge, The Royal Society of Chemistry, pp 647-650. 
Saglio P, Trijasse S (1998) Behavioral responses to atrazine and diuron in goldfish. Arch Environ Contam Toxicol 35: 484-491.

Steinberg CEW, Lorenz R, Spieser OH (1995) Effects of atrazine on swimming behavior of zebrafish, Brachydanio rerio. Water Res 29: 981-985.

Tryfonos M, Antonopoulou E, Papaefthimiou C, Chaleplis $G$, Theophilidis G (2009) An in vitro assay for the assessment of the effects of an organophospate, paraoxon, and a triazine, atrazine, on the heart of the gilthead sea bream (Sparus aurata). Pestic Biochem Physiol 93: 40-46.

Velisek J, Stara A, Kolarova J, Svobodova Z (2011) Biochemical, physiological and morfological responses in common carp (Cyprinus carpio L.) after long-term exposure to terbutryn in real environmental concentration. Pestic Biochem Physiol 100: 305-313.

Waring CP, Moore A (2004) The effects of atrazine on Atlantic salmon (Salmo salar) smolts in fresh water and after sea water transfer. Aquat Toxicol 66: 93-104.

Yang L, Ho NY, Alshut R, Legradi J, Weiss C, Reischl M, Mikut R, Liebel U, Müller F, Strahle U (2009) Zebrafish embryos as a models for embryotoxic and teratological effects of chemicals. Reprod Toxicol 28: 245-253.

Zhou QX, Xie GH, Pang L (2008) Rapid determination of atrazine in environmental water samples by a novel liquid phase microextraction. Chinese Chem Lett 19: 89-91. 